\title{
The functional assessment Berg Balance Scale is better capable of estimating fall risk in the elderly than the posturographic Balance Stability System
}

\author{
A avaliação funcional Berg Balance Scale é capaz de estimar melhor o risco de quedas em \\ idosos do que a posturografia Balance Stability System
}

Vanessa Vieira Pereira1', Roberto Alcantara Maia², Sonia Maria Cesar de Azevedo Silva ${ }^{3}$

\begin{abstract}
The purpose of this study was to verify which instrument better identifies recurrent falls in the elderly. Ninety-eight old people, with an average age of $80 \pm 4$ years, were submitted to an assessment of balance and fall risk by means of the Berg Balance Scale (BBS) and the posturographic Balance Stability System (BSS). The BBS was correlated with the BSS $(r=-0.27 ; p=0.008)$, age $(r=-0.38 ; p<0.001)$ and number of falls $(r=-0.25 ; p=0.013)$ and the analysis of logistical regression showed that the elderly classified with fall risk on the BBS presented 2.5 ( $95 \% \mathrm{Cl}$ 1.08-5.78) more chance of identifying who had two falls or more over the last year. The BBS identified that the greater the age the worse the functional balance and demonstrated a greater capacity to identify falls risk suffered over the last year when compared with the BSS.
\end{abstract}

Key words: postural balance, accidental falls, aged, geriatric assessment.

\section{RESUMO}

A proposta do estudo foi verificar o instrumento que melhor identifica o risco de quedas recorrentes em idosos. 0 estudo incluiu 98 idosos, com média de idade de $80 \pm 4$ anos, submetidos à avaliação do equilíbrio e risco de quedas por meio da Berg Balance Scale (BBS) e da posturografia Balance Stability System (BSS). A BBS foi correlacionada com a BSS ( $r=-0,27 ; p=0,008)$, com a idade $(r=-0,38$; $p<0,001)$ e com 0 número de quedas $(r=-0,25 ; p=0,013)$. A análise de regressão logística mostrou que idosos classificados com risco de quedas na BBS apresentaram 2,5 (95\% IC 1,08-5,78) mais chances de identificar quem teve duas quedas ou mais no último ano. A BBS identificou que quanto maior a idade pior é o equilíbrio funcional e demonstrou maior capacidade de identificar o risco de quedas sofridas no último ano quando comparada a BSS.

Palavras-Chave: equilíbrio postural, acidentes por quedas, idoso, avaliação geriátrica.

Falling is a common event, experienced by everybody during life. In the elderly, it is more serious on account of the consequences and constitutes a major cause of morbidity and mortality ${ }^{1}$. It could be defined as an unintentional dislocation of the body to an inferior level to the initial position, with incapacity for correction in due time and a multifactor ethol$\mathrm{ogy}^{1}$. However, recent research has concluded that the fall has not been defined yet, since it holds a different significance for groups of the elderly, health professionals and researchers the former two associating the events with its antecedents and consequences whereas the researchers are concerned with the event itself ${ }^{2}$.

Two conditions must be satisfied for a fall to occur: there must be a perturbation of balance and a failure of the balance system to compensate and anticipate this perturbation $^{3-7}$. Balance or postural stability is defined as the capacity

Study carried out at the Hospital do Servidor Público Estadual Francisco Morato de Oliveira, São Paulo SP, Brazil.

${ }^{1}$ Physiotherapist specialized in multidisciplinary attendance in Geriatrics and Gerontology, Masters in Health Sciences at the Instituto de Assistência Médica ao Servidor Público Estadual (IAMSPE), São Paulo SP, Brazil;

²E.N.T. specialist, Masters from Universidade Federal de São Paulo (UNIFESP), Doctorate from IAMSPE, São Paulo SP, Brazil.

${ }^{3}$ Neurologist, Masters and Doctorate from UNIFESP, São Paulo SP, Brazil.

Conflict of interest: There is no conflict of interest to declare.

Correspondence: Vanessa Vieira Pereira; Estrada dos Galdinos 857 / casa 19; 06710-400 Cotia SP - Brasil; E-mail: vanessazen@hotmail.com

Received 09 April 2012; Received in final form 30 August 2012; Accepted 06 September 2012 
to maintain the projected center of the mass within the limits of its supporting base in static or dynamic situations ${ }^{8}$.

When broaching upon balance, it is necessary to understand the theory of the systems which comprehend the integration of sensorial systems, central processing and the effector system. The sensorial system represents information relating to corporal stability through three integrated apparatus: vestibular, visual and somatosensorial. The vestibular system is sensitive to movement, with linear acceleration or cephalic angles, spatial orientation and the verticality of the head; the visual apparatus reflects the information of space in relation to the individual and lastly the somatosensorial, which indicates the positioning and velocity of the corporal segments in relation to the medium. This sensorial information are integrated and processed in the central nervous system, provoking responses through the effector system, that is composed of muscles, ligaments and articulations, by means of anticipatory and reactive strategies which make the recuperation of balance possible so that a fall does not occur ${ }^{4,7,9-11}$.

It is known that the ageing process provokes alterations in the systems responsible for balance, as well as altering the motor strategies, the reactive and anticipatory postural control and the limits of stability ${ }^{1,9,10,12-14}$.

The elderly who present damage in one or more systems responsible for balance develop a larger risk for suffering recurrent falls, making a miniscule assessment necessary ${ }^{14}$.

The objectives of a balance assessment are to identify alterations in the balance mechanisms, to characterize their causes, to assess the repercussions on functional activities and to institute adequate and specific treatment to prevent falling ${ }^{14}$.

The Berg Balance Scale (BBS) assesses the functional performance of balance through functional tasks that require equilibrium $^{13-16}$, and the posturography Balance Stability System (BSS) assesses neuromuscular control through the quantification of the individual's ability to maintain dynamic postural stability upon an unstable surface ${ }^{14,17-19}$.

The BBS has been widely used in scientific research and in clinical practice, since, apart from its low cost, it is easy to apply and assesses the risk of falling within the elderly. The BBS assesses balance in an objective form, but has been little used in research on falls within the aged population. A previous pilot study showed a correlation between the two instruments, but did not clarify the choice of instrument which best identifies the elderly with a history of falls ${ }^{20}$.

The object of this study was to verify the instrument (BBS/BSS) which better identified recurrent falls in the elderly over the last year and to analyze its correlations with age.

\section{METHOD}

This is a transversal, descriptive and observational study.

Ninety-eight elderly people were selected aged between 72 and $89(80 \pm 4)$ who were sent to the falls unit for geriatric and chronic cases at the Hospital do Servidor Público Estadual Francisco Morato de Oliveira, during the period from January 2007 to December 2009. Twenty-one individuals (21.4\%) were of the male sex and seventy-seven (78.6\%) of the female sex. The age range of the old people assessed was chosen in accordance with the separation into groups carried out for the normatization of posturography, including exclusively elderly individuals.

Participants were informed about the research by means of a term of consent freely adopted and clarified, and this project was judged by the Committee of Medical Ethics of the Hospital do Servidor Público Estadual and approved under protocol 123/08.

Excluded from the study, were old people who presented a comprehension deficit which might limit the tasks of the BBS or the platform test of the BSS; old people dependent on a fixed zimmer frame, those who made articulated or exclusive use of a wheelchair and those who were aged under 72 or over 89 .

Initially, an anamnesis was realized showing personal details and the number of falls suffered during the 12 months prior to the investigation.

The BBS was subsequently applied and an assessment carried out on the BSS posturography of the Byodex make, in which the old people were classified into greater or lesser risks. Old people who used a stick were assessed by the BBS with the device, but did not use it for the posturography assessment.

The BBS has 14 items which assess balance during functional activities in daily life; these activities are classified from 0 to 4 , with 0 being the worst mark and 4 the best performance from the realization of independence tasks. The sum of these points can reach a maximum of 56 points - the less points the larger danger to the individual's stability. This scale has a cut mark for the risk of falls, in which individuals with values equal to or above 45 present less risk of falling in the activities assessed ${ }^{13,15}$.

The BSS is a piece of equipment which consists of a multiaxial platform connected to a computer which promotes a visual feedback, providing the person under assessment with the possibility for correcting unbalance that can be adjusted favoring various degrees of inclination, to a maximum of 20 degrees. These inclinations ( 1 to 12 of instability, with one being the most unstable and 12 the most stable) create situations similar to the functional activities which result in instability and permit characterizing the ability of the patient to maintain a stable posture. This platform offers the assessor reports on wide tests, predictive values of bilateral comparison and dynamic limits of stability. These facts can be used to measure and register objectively the patient's capacity to stabilize the articulation involved under dynamic effort.

The risk of falling is determined by instability of degree 8 (slightly unstable) in which the individual must maintain himself in line with the center of the platform, generating a score. This value is compared with a data bank of healthy North American individuals in which the reference values 
were obtained in accordance with the height and age range of the individuals. This test is carried out in three attempts of 20 seconds, with an interval of 10 seconds between them, and the inclination goes from levels 12 to 8 . The old people assessed did not wear a safety belt to carry out the test and, if they leaned upon the supporting bar attached to the apparatus, the test was interrupted. The feet were positioned in a comfortable manner, but the distance between them could not exceed their shoulder width; additionally, the feet remained immobile during the three tests. The final result is the average sum obtained from the three scores, considering a variation of central pressure (COP) as reference. For old people aged between 72 and 89 , a fall risk is considered when the individual presents a final test score of above $3.5^{21}$.

When questioned upon having falls over the last year, 25 old people replied they had not fallen in the last year, 26 reported having one fall and 47 reported having two or more falls, suggesting the formation of three groups of individuals. Therefore, we opted to divide the patients into two groups: old people who suffered zero to one fall over the last year $(0$ to 1 fall) and old people who suffered recurring falls, i.e., two or more falls in the last year ( $\geq 2$ falls).

The variables used were sex, age, number of falls, BBS score, BSS score and fall risk in each one of the assessments.

The data were stored in a data bank and analyzed with a statistical package SPSS (Statistical Package for Social Sciences, version 18.0). The descriptive average analysis, standard deviance and the analysis of frequencies were used to present the data. The distribution of data was verified by means of the Kolmogorov-Smirnov test and presented normal distribution. The comparison between the groups 0 to 1 fall and 2 falls or more was realized by the Student $t$-test for independent samples. Furthermore, a Pearson correlation was used to establish possible relations between the scores obtained from BBS and the scores from the BSS platform with the age and number of falls suffered over the last year. The logistic regression analysis with forced entry of the dichotomized independent variables in the fall risk from the BBS and the fall risk from the BSS was used to verify the capacity of identifying who had suffered two falls or more over the last year ${ }^{22}$. The two dimensional graph of the correspondence analysis (ANACOR) together with Pearson's qui-square association test were used to visualize the associations encountered through analysis of logistic regression. For all the variables, the level of significance adopted was $5 \%(\mathrm{p}<0.05)$.

\section{RESULTS}

Table 1 shows the average age, the number of falls over the last year, the BBS mark and the score on the BSS platform. There was a significant difference for the number of falls between the groups.

The Pearson correlation test showed a significant moderate negative relation between age and the BBS marks $(r=-0.38$; $\mathrm{p}<0.001)$ and a weak negative relation between the BBS marks and the BBS platform scores $(r=-0.27 ; p=0.008)$. A weak, but significant negative, relation was also found between the BBS marks and the number of falls in the last year $(\mathrm{r}=0.25 ; \mathrm{p}=0.013)$. There was no relation between the BSS scores and age $(r=0.05$; $\mathrm{p}=0.606)$ and with the number of falls suffered in the last year $(\mathrm{r}=0.04 ; \mathrm{p}=0.656)$.

In Table 2, it is observed that from the group of elderly who were classified with fall risk on the BBS, $60 \%$ related having suffered two or more falls during the last year, whilst in the group of old people without fall risk, 35\% related having suffered two or more falls during the last year. However, for the old people with risk classification for fall on the BSS platform, $55 \%$ of them suffered two or more falls over the last year, whereas $37 \%$ of those who did not present risk on the BSS related having suffered two fall or more over the last year.

Table 3 shows the analysis of logistic regression. The classification of greater fall risk in the marking of the BBS has 2.5

Table 1. Distribution of the number of fall occurrences in relation to age, score from Berg Balance Scale and Balance Stability System.

\begin{tabular}{lccc} 
& \multicolumn{2}{c}{ Groups } & \\
\cline { 2 - 3 } & 0 to 1 fall $(n=51)$ & $\geq 2$ falls $(n=47)$ & \\
\hline Age & $79.4 \pm 4.7$ & $80.7 \pm 4.2$ & 0.141 \\
Number of falls & $0.6 \pm 0.5$ & $3.2 \pm 1.8$ & $<0.001 *$ \\
BBS Score & $44.7 \pm 7.3$ & $42.1 \pm 7.3$ & 0.073 \\
BSS Score & $4.4 \pm 2.3$ & $4.7 \pm 2.5$ & 0.544 \\
\hline
\end{tabular}

*Significant difference due to the definition of the groups. Student $t$-test for independent samples. BBS: Berg Balance Scale; BSS: Balance Stability System.

Table 2. Fall risk on the Berg Balance Scale and Balance Stability System in relation to the number of falls.

\begin{tabular}{|c|c|c|c|c|c|c|}
\hline & & \multicolumn{2}{|c|}{ Groups } & \multirow{2}{*}{ Total } & \multirow{2}{*}{$\chi^{2}$} & \multirow{2}{*}{$p$-value } \\
\hline & & 0 to 1 fall & $\geq 2$ falls & & & \\
\hline \multirow{3}{*}{ BBS } & with risk & $21(40 \%)$ & $31(60 \%)$ & $52(100 \%)$ & & \\
\hline & without risk & $30(65 \%)$ & $16(35 \%)$ & $46(100 \%)$ & 6,031 & 0,014 \\
\hline & Total & $51(52 \%)$ & $47(48 \%)$ & $98(100 \%)$ & & \\
\hline \multirow{3}{*}{ BSS } & with risk & $27(45 \%)$ & $33(55 \%)$ & $60(100 \%)$ & & \\
\hline & without risk & $24(63 \%)$ & $14(37 \%)$ & 38 (100\%) & 3,073 & 0,080 \\
\hline & Total & $51(52 \%)$ & 47 (48\%) & $98(100 \%)$ & & \\
\hline
\end{tabular}

$\chi^{2}$ : Pearson qui-square test. BBS: Berg Balance Scale; BSS: Balance Stability System. 
Table 3. Association between the risk of falling obtained by the Berg Balance Scale and Balance Stability System and the number of falls suffered over the last year. With Odds Ratio estimate and a Confidence Interval of $95 \%$.

\begin{tabular}{|c|c|c|c|c|c|}
\hline \multirow{2}{*}{ Variable } & \multirow{2}{*}{$\mathrm{B}$} & \multirow{2}{*}{ Wald } & \multirow{2}{*}{ OR } & \multicolumn{2}{|c|}{ 95\% Confidence Interval } \\
\hline & & & & Inferior & Superior \\
\hline \multirow{2}{*}{ Constant } & -0.92 * & \multirow{2}{*}{5.52} & \multirow{2}{*}{0.40} & & \\
\hline & $(0.39)$ & & & & \\
\hline \multirow{2}{*}{ Risk on the BBS } & 0.92 * & \multirow{2}{*}{4.57} & \multirow{2}{*}{2.50} & \multirow{2}{*}{1.08} & \multirow{2}{*}{5.78} \\
\hline & $(0.43)$ & & & & \\
\hline \multirow{2}{*}{ Risk on the BSS } & 0.57 & \multirow{2}{*}{1.66} & \multirow{2}{*}{1.76} & \multirow{2}{*}{0.74} & \multirow{2}{*}{4.18} \\
\hline & $(0.44)$ & & & & \\
\hline
\end{tabular}

Logistic Regression, $R^{2}=0,40$ Cox e Snell. $\chi^{2}$ of model=7,768, $p=0,021 ;{ }^{*} p<0,05$. OR: Odds Ratio; BBS: Berg Balance Scale; BSS: Balance Stability System.

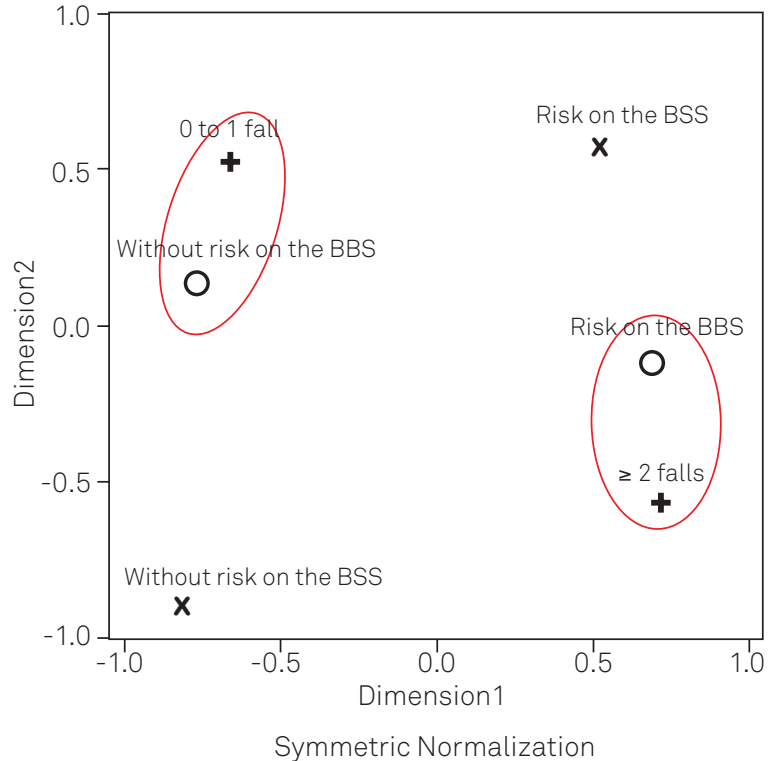

BBS: Berg Balance Scale; BSS: Balance Stability System.

Figure. Graph of the association of the two dimensions between the risk groups assessed by the Berg Balance Scale and Balance Stability System.

(95\%CI 1.08-5.78; $p=0.032$ ) more chance of identifying those who presented two or more falls in the past year. On the other hand, the risk classification for falls on the BSS platform was not capable of identifying the elderly who suffered falls in the last year ( $p=0.198)$. The graph of proximities of the two dimensions generated by the correspondence analysis illustrates these findings (Figure).

As we can observe on the graph, the elderly who related having suffered two or more falls over the last year are closer to the old people with classification of fall risk on the Berg Balance Scale. As the old people with and without risk classification for falls are equidistant from the association between the number of falls suffered over the last year, it is supposed that both the elderly with a risk classification and those without the risk classification for falls on the Balance Systems platform present similar results, confirmed by Pearson's quisquare test $\left(\chi^{2}(1)=3.073 ; p=0.080\right)$.

\section{DISCUSSION}

In the present study, it was observed that the BBS correlated negatively with the age of the elderly assessed, i.e., the lower the marks on the scale the higher the age of the old people, demonstrating that old people with older age ranges present a greater risk of falls. The ageing process provokes alteration in the systems responsible for balance, causing deficits in motor balance strategies, reducing the reactive and anticipatory postural control and the limits of stability.

Similar findings were met in another studies in which it was verified that the age range above 80 presents a greater risk of falling ${ }^{23}$ and that the association between factors related to balance of old people and chronic vestibular function, observing a correlation between the scale and the age ${ }^{24}$. However, these findings were not met in a cohort study which verified the factors associated to the risk of falling in the aged of the community, where the age was not related to the occurrence of falls ${ }^{25}$, and to a study upon prediction of falls utilizing the BBS in which there was no relation observed between age increase and the decreasing performance on the scale $^{15}$.

A weak negative relation was verified between the BBS and the BSS platform, i.e., the greater the value of the score on the platform the lower will be that of the scale, since the greater the marks on the platform the greater the risk of falls and the lower the marks on the Berg scale the greater the disequilibrium and risk of falling. It is, therefore, observed that there does exist a relation, albeit weak, between the two methods of assessment, since both assess balance, with its systems involved and the risk of falls, but the tasks assessed which require the balance are different.

There are various assessment tests for balance all of which present positive aspects and limitations. Upon comparing different tests, it is verified that there are some 
tasks which associate and others that differentiate, and this can be observed in the present study. The same can be observed in a comparative study between BBS, the Dynamic Gait Index and the Timed Up and Go Test, in which the tests are associated, however only the second test was capable of verifying the fall risk in the population studied constituted by old people of a younger age (from 60 to 75 years old), who had not suffered recent falls ${ }^{26}$.

In a bibliographic revision upon the best form of assessing fall risk, it was suggested that the BBS score associated with history of falls were the best predictors of falls among the elderly in the community. Another study demonstrated that old people who fell during the last 12 months prior presented a score varying from 54 to 56 points, that is to say the Scale on its own is not a good predictor of fall risk ${ }^{27}$.

The BBS assesses balance in functional activities, but does not examine the performance under altered environmental conditions, and none of the tasks demand reactive postural control, different from the BSS platform which demands reactive postural control, since it provokes instability in the patient through unexpected movements at the base of its support, stimulating him to stabilize by means of visualization on the computer and by the utilization of balance strategies ${ }^{28}$.

Both tests assess the balance of the old person and the systems involved within balance, but the BSS platform demands a little more than the functional activities assessed in the BBS, on which account it is observed that the average mark of the two groups ( 0 to 1 fall and more than 2 falls) on the BSS was high, verifying the risk of falls in the elderly who fell more than once and in the elderly who fell once only or not at all. Perhaps, if the test were realized on the platform on the static level, it would be possible to differentiate the two groups assessed as in the Bauer study or by carrying out functional tasks upon the platform ${ }^{29}$. The public studied is considered old and very old; it is known that this population presents the systems involved in altered balance and this becomes more evident in situations of higher demand on these systems than in the habitual situations such as those assessed by the BBS.

In the logistic regression analysis, it can be observed that the BBS was capable of identifying 2.5 times more those who had fallen twice in the last year, which was not verified on the
BSS platform; with this, it can be stated that the Scale has a better power for verifying falls suffered in the last year compared to the platform. We part from the hypothesis that the falls of these elderly occurred in similar situations to those assessed by the BBS, such as getting up from a chair, diminishing the basis of support, turning on their own axis and diminishing visual stimulus, amongst others, and that the elderly of the two groups would undergo a risk of falling in situations in which a reactive postural control is required, as provoking instability by means of oscillation at the base of sustentation assessed by the posturography, which simulates activities outside the home, like going to a crowded shopping center, ascending a moving staircase and brusque changes of direction and speed ${ }^{30}$.

In contrast, it was verified in a study in which old people with and without symptoms of dizziness were assessed by the computerized dynamic posturography that there was a statistically significant difference between the groups assessed; the groups, however, were separated into adults without symptoms, old people aged between 61 and 79 years with symptoms of unbalance or dizziness and old people of the same age range without the referred symptoms ${ }^{17}$. As can be observed, the age range of the group studied is less than the age range assessed in the present study, which modifies the motor responses in the face of instability.

According to the findings of the present study, it is observed that the BBS was better for identifying who suffered falls in the previous year when compared to the BSS, apart from there being a correlation between the tests. This is very important for the physiotherapist since the BBS is an instrument of low cost and easy application, able to be used in diverse contexts in which the aged public are found, whilst the BSS is only available in few Brazilian health services for the assessment of balance and fall risk.

Although exists a correlation between the two methods of assessment, it is concluded that the BBS permitted verifying that the elderly with older age ranges have a tendency to present worse balance and demonstrated a greater capacity to identify falls suffered over the last year when compared with the BSS platform.

It is possible that some of these observations may be reformulated when dealing with a larger casuistry of elderly patients and that correlations with other variables might also enrich this study. 


\section{References}

1. Menezes RL, Bachion MM. Estudo da presenca de fatores de riscos intrínsecos para quedas, em idosos institucionalizados. Cienc Saude Colet 2008;13:1209-1218.

2. Zecevic AA, Salmoni AW, Speechley M, Vandervoort AA. Defining a fall and reasons for falling: comparisons among the views of seniors, health care providers, and the research literature. Gerontologist 2006;46:367-376.

3. Paixão Junior CM, Heckmann M. Distúrbios da postura, marcha e quedas. In: Freitas EV, Py L, Neri AL et al. (eds). Tratado de geriatria e gerontologia. São Paulo: Guanabara KOOGAN; 2002. p. 624-634.

4. Horak FB. Postural orientation and equilibrium: what do we need to know about neural control of balance to prevent falls? Age Ageing 2006;35:S7-S11.

5. Godoi D, Barela JA. Mecanismos de ajustes posturais Feedback e Feedforward em idosos. Rev Bras Cienc Esporte 2002;23:9-22.

6. Shumway-Cook A, Woolacott $\mathrm{MH}$. Control of posture and balance. In: Shumway-Cook A, Woolacott MH (eds). Motor control theory and practical applications. Maryland: Willians \& Wilkins; 1995.

7. Shumway-Cook A, Woollacott MH. Fisiologia do controle motor. In: Shumway-Cook A, Woollacott MH (eds). Controle motor: teorias e aplicações práticas. Barueri: Manole; 2003. p. 47-84.

8. Shumway-Cook A, Woollacott MH. Controle Postural Normal. In: Shumway-Cook A, Woollacott MH (Eds). Controle motor: teorias e aplicações práticas. Barueri: Manole; 2003. p. 53-178.

9. Gazzola JM, Ganança FF, Perracini MR, Aratani MC, Dorigueto RS, Gomes CMC. Envelhecimento e sistema vestibular. Fisioter Mov 2005;18:39-48.

10. Mann L, Kleinpaul JF, Teixeira CS, Rossi AG, Lopes LFD, Mota CB. Investigação do equilíbrio corporal em idosos. Rev Bras Geriatr Gerontol 2008;11:155-165.

11. Massion J. Postural control system. Curr Opin Neurobiol 1994;4:877-887.

12. Shumway-Cook A, Woolacott MH. Envelhecimento e controle postural. In: Shumway-Cook A, Woollacott MH (eds). Controle motor: teoria e aplicações práticas. Barueri: Manole; 2003. p. 209-231.

13. Miyamoto ST, Lombardi Junior I, Berg KO, Ramos LR, Natour J. Brazilian version of the Berg balance scale. Braz $J$ Med Biol Res 2004;37:1411-1421.

14. Gazzola JM, Perracini MR. Balance em idosos. In: Perracini MR, Fló CM (eds). Funcionalidade e envelhecimento. São Paulo: Guanabara KOOGAN; 2009.

15. Bogle Thorbahn LD, Newton RA. Use of the Berg Balance Test to predict falls in elderly persons. Phys Ther 1996;76:576.

16. Berg KO, Wood-Dauphinee SL, Williams JI, Maki B. Measuring balance in the elderly: validation of an instrument. Can $J$ Public Health 1992;83:S7-S11.
17. Pedalini ME, Cruz OL, Bittar RS, Lorenzi MC, Grasel SS. Sensory organization test in elderly patients with and without vestibular dysfunction. Acta Otolaryngol 2009;129:962-965.

18. Suarez H, Arocena M. Las alteraciones del equilibrio en el adulto mayor. Rev Med Clin Condes 2009;20:401-407.

19. Perron M, Hébert LJ, McFadyen BJ, Belzile S, Regniére M. The ability of the Biodex Stability System to distinguish level of function in subjects with a second-degree ankle sprain. Clin Rehabil 2007;21:73-81.

20. Mota RS, Dias BB, Gênova TC, Tamborelli V, Puccini PT, Pereira VV. Concordância entre a Escala de Berg Balance e o Biodex Balance System para predizer risco de quedas em idosos. Rev Med IAMSPE 2007;32:129-134

21. Fin J. Biodex Balance System assessment amount subjects of disparate balance abilities. In: American College of Sports Medicine Meeting. Southern Connecticut State University. 1999

22. Bagley SC, White H, Golomb BA. Logistic regression in the medical literature: standards for use and reporting, with particular attention to one medical domain. J Clin Epidemiol 2001;54:979-985.

23. Dias BB, Mota RS, Gênova TC, Tamborelli V, Pereira VV, Puccin PT. Aplicação da escala de equilibrio de Berg para verificação do equilibrio de idosos em diferentes fases do envelhecimento. Rev Bras de Ciên do Envelh Hum 2009;6:213-224.

24. Gazzola JM, Perracini MR, Gananca FF. Fatores associados ao equilibrio funcional em idosos com disfunção vestibular crônica. Rev Bras Otorrinolaringol 2006;72:683-690.

25. Perracini MR, Ramos LR. Fatores associados a quedas em uma coorte de idosos residentes na comunidade. Rev Saude Publica 2002;36:709-716

26. Rodini C, Ferreira LTD, Pirré GE, Hino M, Alfieri FM, Riberto M. Estudo comparativo entre a Escala de Equilibrio de Berg, o Teste Timed Up \& Go e o Índice de Marcha Dinâmica quando aplicadas em idosos hígidos. Acta Fisiátrica 2008;15:267-268.

27. Persad CC, Cook S, Giordani B. Assessing falls in the elderly: should we use simple screening tests or a comprehensive fall risk evaluation? Eur J Phys Rehabil Med 2010;46:249-259.

28. Mancini M, Horak FB. The relevance of clinical balance assessment tools to differentiate balance deficits. Eur J Phys Rehabil Med 2010;46:239-248.

29. Whitney SL, Marchetti GF, Schade Al. The relationship between falls history and computerized dynamic posturography in persons with balance and vestibular disorders. Arch Phys Med Rehabil 2006;87:402-407.

30. Chaudhry H, Bukiet B, Ji Z, Findley T. Measurement of balance in computer posturography: Comparison of methods - A brief review. $J$ Bodyw Mov Ther 2011;15:82-91. 